\title{
Judo sport regulations for children's parents in the pre- school children judo education: study of field
}

\author{
Şengül DEMİRAL
}

Trakya University, Kırkpinar College of Physical Education and Sports, Edirne/Turkey

Address Correspondence to Ş. Demiral, e-mail: senguldemiral@trakya.edu.tr

\begin{abstract}
The fact that children have been acquainted with sports from their early years is an important determinant of their attitudes and behaviors in their future lives and constitutes the most basic part of a country's athletic resource in broadcast sports policies. Early childhood is important in supporting the development of children as well as in acquiring certain habits. Quality management of this time zone is also important. For this reason, in this research, it was aimed to examine the opinions and expectations of the parents of preschool children who are in pre-school education to direct their children to judo sports. The data are arranged in categories, interpreted as descriptive and frequency. As a result, according to priority order; it is important for the female parents that their children are healthy, develop their own discipline, learn sports culture and morality. Moreover, they want them to be psychologically good and healthy as well as expecting them to socialize, learn sports culture and morality, develop their self- discipline. Also, they are guiding their children to judo sports because they want to improve morality, social cohesion and self-discipline. The results obtained in Turkey Judo Federation and judo policies will be developed in preschool education for coaches, and will create significant resources and proposals for the strategy which has been developed for data.
\end{abstract}

Keywords: Preschool period, Judo, parent, active movement, orientation.

\section{INTRODUCTION}

Today, sport is now considered as a lifestyle and it is mainly aimed at serving individuals and their lives. In this process, sports and all studies related to it can be made sustainable depending on the shaping of individuals (13). Sport is a professionally chosen area that is preferred for the needs of the individual to meet, play, cheer, socialize, get status and for many other reasons; it is all of the body movements that are made in personal or collective form and are usually applied to certain rules, which are based on competition $(3,14,26)$. Sport gives a healthy life style to the individuals from all ages, and protective tibbles have begun to take place in our lives again by creating alternative sources. In addition to this function of sports, it is also clear that adults who will be charged with responsibility in the society have a positive influence on getting good habits and establishing healthy relations with individuals and society. Thanks to this, children are encouraged to participate in sports and physical education programs, starting from early ages, with the importance of sport in developed countries, since children's meeting with sport from early years is an important determinant of their attitudes and behaviors about sports in their future lives $(23,33,9,20)$. In particular, sport changes and reemerges through relationships in society (32). In this context, the child is the first social institution that provides the concept of sports, sports and the sporting world. The ability to determine whether the children are interested in the sports, involvement, participation in sports activities, and how to participate if they do is shaped by the predictions of the families.

Activities in the Preschool Period; From early ages, sustainability should be supported since it is inevitable that sport becomes an indispensable part of natural life if the love of sport created by the influence and support of the individuals are reinforced by teachers, peer groups and other adults in the future $(13,5)$. The children want to know their power among their peers in order to get to know themselves. For this, they also run, jump, climb, play freely. Sports games and activities that enter their lives in the early period due to this unlimited need for playing during the children's basic development enable them to coexist with 
their peers and to gain experiences such as adherence to rules, decisions, ingestion and despair. At the same time, they have the opportunity to recognize their own bodies, to realize their physical characteristics, to compete without harming others and to be successful $(12,17,7)$. All kinds of sporting activities are of great importance in terms of developing children's motor skills and abilities in the process of growth and development as well as ensuring that they gain positive behaviors and that they are able to maintain and be healthy in sports habits. For this reason, all studies related to sport benefits reveal the need sport to enter the children's lives as early as possible $(2,6,35,18)$. Children gain different communication experiences by establishing different relationships from their daily lives with all kinds of sporting events such as the ones with family members, teachers or friends at home, in schools, in parks and gardens, at gymnasiums or on sport fields. Given that these gains and the effects of sport on the physical, social, mental and spiritual development of children are evaluated, it is understood that more physical, emotional, cognitive duties and responsibilities fall into adults who are interested in children $(23,22)$. It is stated that the most important factor in the children's sport orientation is the family, and that this orientation is increased parallel to the education level of the parents and that the children who are encouraged to the sports by their families have a healthier socialization process and become more successful throughout their lives. It is also emphasized that adolescents in adulthood are related to sporting activities in childhood. According to these findings, it can be considered that the individuals engaged in sports in childhood are related to sports in adulthood, and the adults who are related to sport encourage their children to do sport. The result is that one of the most important factors in the spread of sport in society is the participation of sports in childhood $(1,4,20,17)$. It has been determined that the education and income levels of parents and the presence of athletes in the family are effective in the direction of the sport from early years (20). All of this shows that family factor is the most influential factor on sport, and that individuals' acquaintance with sport from early ages is a determinant of their attitudes and behaviors in relation to sports in their future lives.
When the studies done in our country are examined, it is seen that the family, social environment, friends, etc. are important and also it is seen that the items were searched and the studies were mostly performed with the second grade and above age groups. While it is accepted today that the child-sports meeting is as early as possible, unfortunately, there have been no studies in the pre-school period that focus on children's views other than classroom sports activities. For this reason, this study was carried out for examining the causes of the sport orientation of the children who had received the preschool judo education. While there were different sports branches in the first place, why did parents direct their children to judo sports? It was aimed to identify the main topics of the reasons. When it is clarified by a few literary studies to find an answer to the question 'How does judo sport contribute to child development before doing these examinations, strengthening the bones and muscles,improving flexibility, posture and balance, reducing stress and ensuring sleep patterns as well as improving the quality of life?' ,it also contributes to the development of judo education, five motor skills, general body coordination, hand-eye coordination, foot-eye coordination, static and dynamic balance, which helps children to maintain healthy weight, to help children move talentedly and to enjoy being active. It is also seen that Judo is training the values with the values and preparing the infrastructure of the lifelong sport habit by providing value with 'Respect, Courtesy, Taking, Self-control, Solidarity, Honesty, Friendliness, Patience, Courage, Humility' $(27,30,31)$. It is also a struggle that requires mental and physical skills of judo. In other words, Judo is an art in which mental and muscle power is used effectively. Judo's word meaning 'Ju' means softness, agility and flexibility; 'Do' means path, principle and discipline (21).

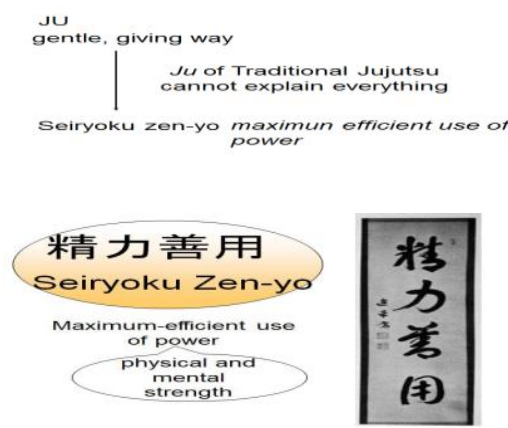

Figure 1. Ju-Do ve Seiryoku Zen-yo 
As seen in Figure 1, Judo sport is not just a sport, it is more than a sport. It is the art of using mental and physical force most efficiently. Because it is a sport that contributes to the mental and physical development of the child (24). It is assumed that parents are influential in directing their children to judo sports. For this reason, it was aimed to

\section{MATERIALS \& METHOD}

The descriptive method of qualitative research methods was used in the research. The data are described within themselves. Descriptive method is the method used to investigate a given situation, to make assessments in line with the standards and to reveal the possible relationships between events $(8,10)$. In this study, the reasons for the orientation of preschool children to judo sports were examined in the direction of their parents' opinions.In the determination of the study group, the "convenience sampling" technique was used. Since this method of

\section{RESULTS}

Table 1. Age and sex distribution of male and female judoists participating in the study.

\begin{tabular}{llccc}
\hline Kids gender & $\mathrm{N}$ & Age-5 boys & Age-6 boys \\
\hline $\begin{array}{l}\text { Boys the number of } \\
\text { judokas }\end{array}$ & 38 & 21 & 17 \\
\hline
\end{tabular}

In table 1 shows the participation of 3 male, 3 female, 5 year old male, 5 male, 6 male, 6 male, 6 year old male judo are attending.

Table 2. Age and sex distribution of male and female judoists participating in the study.

\begin{tabular}{lccc}
\hline Kids gender & $\mathrm{N}$ & $\begin{array}{c}\text { Age 6 } \\
\text { girls }\end{array}$ & Age-5 girl \\
\hline $\begin{array}{l}\text { Girls the number of } \\
\text { judokas }\end{array}$ & 23 & 14 & 9 \\
\hline
\end{tabular}

In table 2 shows the participation of 14 girls, 6 girls and 5 girls.

Participating in the study; 15 secondary education male and female parents, 10 females and 14 male parental university education, 5 females and 2 male parents receiving M.Sc. and doctoral determine the opinion of the preschool children about the sport orientation in the study.

This includes the parents' children; judo has been tried to examine why, why and how to direct the sport, how to make the information and preferences about how to contribute to the children of judo sports, and suggestions for supporting judo activities in preschool children.

sampling gives speed and practicality to research, the researcher chooses a situation that is easy to reach (28). Likert questionnaire formulated according to expert opinion was used as data collection tool in the research. Each question was scored from 1 to 5 and the total scores of each problem were evaluated according to the parents' gender, education and income level. This study was also included in the study group of parents of preschool children receiving judo training in special clubs due to limitations in terms of time and labour.

A total of 61 parents participated in the study group.

education (Table 3). It appears that the majority of parents are secondary school educators.50\% of the schools are primary education, $33.3 \%$ are university, $16.6 \%$ are Master and Ph.D., $48.4 \%$ are females, $45.2 \%$ are universities, $6.4 \%$ are $\mathrm{Y}$ Bachelor and Ph.D. These findings show that children have qualities that are similar or different from expectations in terms of family characteristics.

When income levels of parents participating in the study are examined; 29 females and 31 male parents have income over 2600 TL and between 2100-2500 TL. It is seen that there is certain income level for each female parent (Table 3). It seems that the majority of parents have income over 2600TL. This means that the amount of economic income makes it possible to leave the budget necessary to do sports, and we can reach the result that the children have the opportunity to play sports at an early age. 
Table 3. Distribution of educational status of female and male parents participating in the study.

\begin{tabular}{lllll}
\hline Education Status & $\mathrm{N}$ & Secondary education & University & Master and Ph.D. \\
\hline \multirow{2}{*}{ Mother } & \multirow{2}{*}{30} & $\mathrm{f}: 15$ & $\mathrm{f}: 10$ & $\mathrm{f}: 5$ \\
\cline { 3 - 5 } & & $50 \%$ & $33,3 \%$ & $6,6 \%$ \\
\hline \multirow{2}{*}{ Father } & \multirow{2}{*}{31} & $\mathrm{f}: 15$ & $\mathrm{f}: 14$ & $\mathrm{f}: 2$ \\
\cline { 2 - 5 } & & $48,4 \%$ & $\% 45,2$ & $6,4 \%$ \\
\hline
\end{tabular}

Table 4. Distribution of income levels of male and female parents participating in the study.

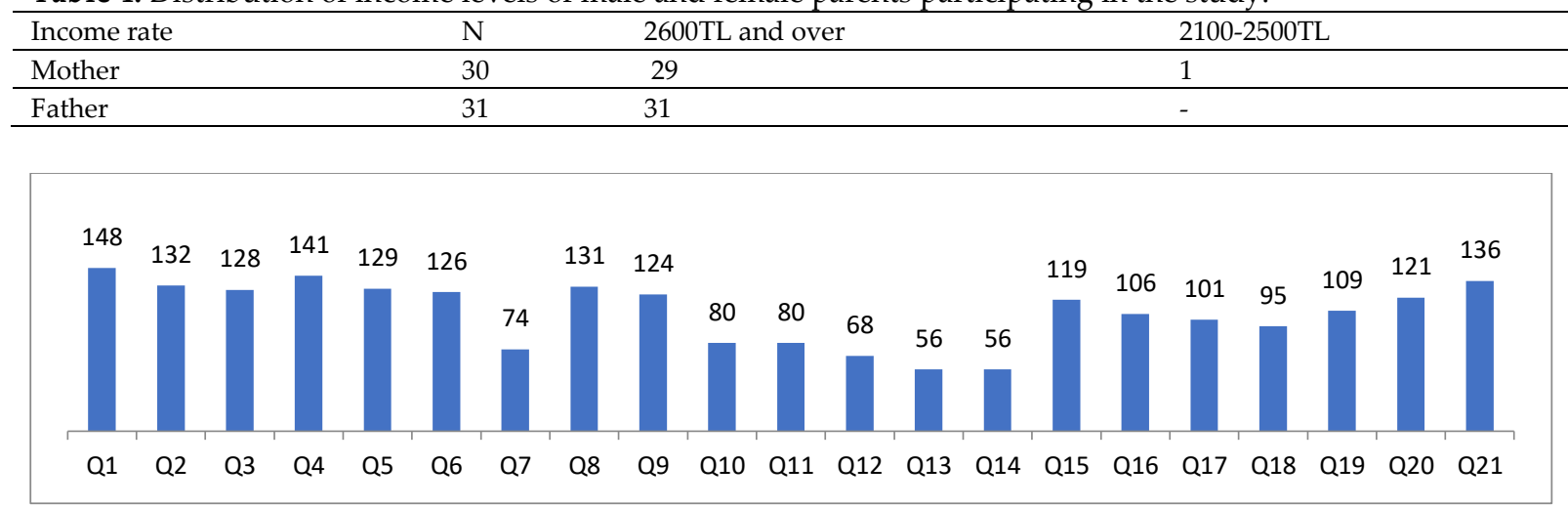

Figure 2.Distribution of the \% slices of the answers given by male parents to the questionnaire.

In figure 2 shows the questionnaires of male parents; 148 points for question1, 132 points for question 2, 128 points for question 3, 141 points for question 4, 129 points for question 5, 126 points for question 6,127 points for question 6,74 points for question 7, 131 points for question 8 , question 9 for 124 points, 80 points for question 10, 80 points for questions 11 and 12, 56 points for questions 13 and 14, 119 points for question 15, 106 points for question 16, 101 points for question 17, 95 points for question 18, question 18 It was observed that they scored 109 points for 19, 121 points for question 20 and 136 points for question 21. According to these data Q1, Q4, Q21, Q2, Q20, Q8, Q5, Q3, Q6, Q9, Q15, Q19, Q16, Q17, Q18, Q10 / Q11, Q7, Q12, Q13 / Q14 are listed in order of priority.

Table 6. Ranking of the first four ranked poll questionnaires of male Parents

\begin{tabular}{lll}
\hline Ranking & Question no & Score \\
\hline First & Q1:To be healty & 148 \\
\hline Second & Q4: To be socialize & 141 \\
\hline Third & $\begin{array}{l}\text { Q21: To learn sports culture and } \\
\text { morality }\end{array}$ & 136 \\
\hline Fourth & $\begin{array}{l}\text { Q2: To improve your-self } \\
\text { discipline }\end{array}$ & 132 \\
\hline
\end{tabular}

In order for children to be healthy in the first place, male parents direct their children to judo
Table 5. Questions that the male parents answered in the same percentage of the answers given to the questionnaire.

\begin{tabular}{ll}
\hline Question No & Percentile \\
\hline Q1 & $7 \%$ \\
\hline Q2_Q3_Q4_Q5_Q6_Q8_Q20_Q21 & $6 \%$ \\
\hline Q9_Q15_Q16_Q19_Q18 & $5 \%$ \\
\hline Q10_Q11_Q17 & $4 \%$ \\
\hline Q7_Q12 & $3 \%$ \\
\hline Q13_Q14 & $2 \%$ \\
\hline
\end{tabular}

In table 5 are examined $7 \%$ of male parents are 'healthy', $6 \%$ are 'improving self-discipline, improving psychological well-being, improving social cohesion, developing empathy skills, improving body coordination, $5 \%$ of them were satisfied with judo education, friends were directed by the effects of school curricula, obesity problem, performance sportsman, $4 \%$ of them were medical orientations (hyperactivity, impulse control problem, the problem of focusing ... etc), the orientation of the teacher, the introduction of judo sports clubs, $3 \%$ being famous, TV program and $2 \%$ being influenced by magazines, newspapers and computer games.

sports in order to socialize in the second place, to learn sports culture and morality in the third place, and to improve their self discipline in the fourth place (Table 6). 


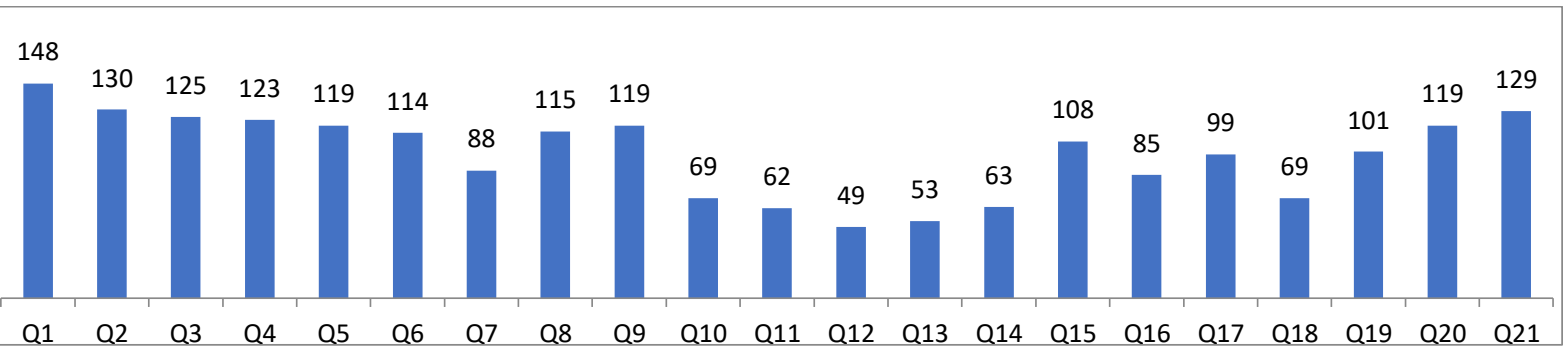

Figure 3. Female represent $\%$ of the answers that parents gave to the survey questions.

In figure 3 shows the questions of female parents that it is 148 points for question1, 130 points for question 2, 125 points for question 3, 123 points for question 4,119 points for question 4, 114 points for question 6, 114 points for question 6, 115 points for question 7, question 9 for 115 points, for question 9119 points, 62 points for question 10, 62 points for question 11, 49 points for question 12, 53 points for question 13, 63 points for question 14, 108 points for question 15, 85 points for question 16, 99 points for question 1769 points for question 18, 101 points for question 19, 119 points for question 20 and 129 points for question 21. According to these data shows in order of priority Q1, Q2, Q21, Q3, Q4, Q5, Q9, Q20, Q8, Q6, Q15, Q19, Q17, Q7, Q16, Q10, Q18, Q14, Q11, Q13, Q12.

Table 7. Ranking of the first four ranks of the questionnaires of female Parents

\begin{tabular}{lll}
\hline Ranking & Question no & Score \\
\hline First & Q1: To be healthy & 148 \\
\hline Second & Q2: To increase self-discipline & 130 \\
\hline Third & $\begin{array}{l}\text { Q21: To learn sports culture } \\
\text { and ethics }\end{array}$ & 129 \\
\hline Fourth & $\begin{array}{l}\text { Q3: To ensure that you are } \\
\text { psychologically good }\end{array}$ & 125 \\
\hline
\end{tabular}

In Table 7 shows that seen that female parents are leading their children to judo sports in order to improve their self-discipline in the first place, to learn sports culture and morality in the third place, and to be psychologically good in the fourth place.

Table 8. The questions that female parents answered in the same percentage of the answers they gave to the questionnaires.

\begin{tabular}{ll}
\hline Question no & Percentile \\
\hline Q1 & $\% 7$ \\
\hline Q2_Q3_Q4_Q5_Q8_Q9_Q20_Q21 & $\% 6$ \\
\hline Q6_Q15_Q17_Q19 & $\% 5$ \\
\hline Q7_Q16 & $\% 4$ \\
\hline Q10_Q11_Q13_Q14_Q18 & $\% 3$ \\
\hline Q12 & $\% 2$ \\
\hline
\end{tabular}

In Table 8 shows that $7 \%$ of male parents are 'healthy', 6\% are 'improving self-discipline, psychological well-being, improving social cohesion, developing empathy skills, contributing to education, enjoying judo education, (hyperactivity, impulse control problem, focusing problem ... etc.), $3 \%$ to improve the quality of sports, to learn sports culture and morality, $4 \%$ to 'improve body coordination, directed by friends, introduction of judo sports clubs, , the direction of the teacher, magazines, newspapers and computer games were obesity problems and they were directed to judo sports because they were influenced by TV program.

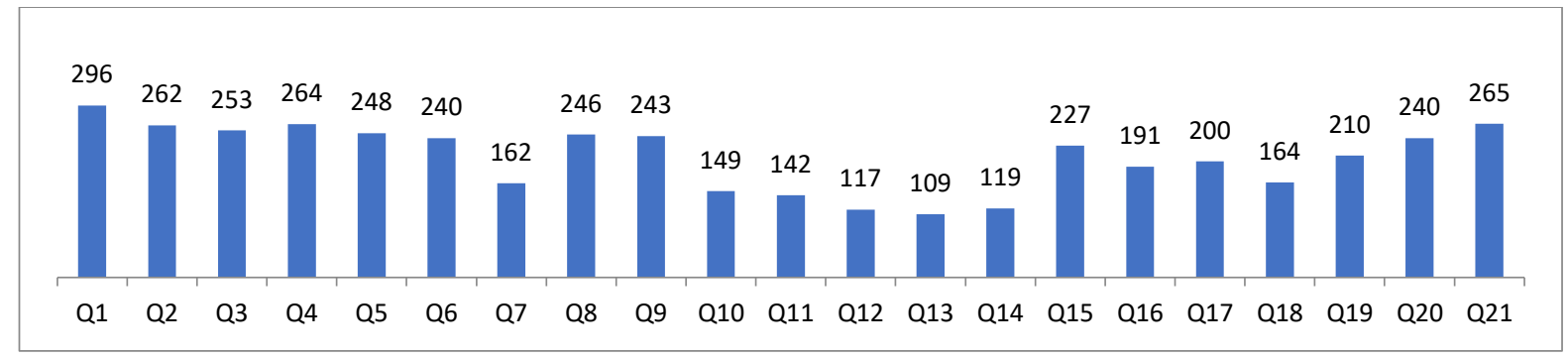

Figure 4.Ranking of the first four ranks of male and female parent survey questionnaires

In figure 4 shows the numerical values of the responses of the female and male parents to the questionnaire. Figure 4 examined; In the first rank with a score of 296 (question1), the second place with 265 points is to learn sports culture and ethics (question21) and it is seen that in third place, with 
264 points, children are directed to judo sport in order to improve their social cohesion.

Table 9. Grading of the first four ranked poll questionnaires of male and female parents

\begin{tabular}{llc}
\hline Ranking & Question no & Score \\
\hline First & Q1: To be healthy & 296 \\
\hline Second & $\begin{array}{l}\text { Q21: To learn sports culture and } \\
\text { ethics }\end{array}$ & 265 \\
\hline Third & Q4: To be social adjustment & 264 \\
\hline Fourth & Q2: To increase self-discipline & 262 \\
\hline
\end{tabular}

In tablo 9 it is seen that male and female parents direct their children to judo sports for their children to be healthy first, for sports culture and morality for second, for social adjustment for third place and for self discipline for fourth place.

\section{DISCUSSION \& CONCLUSION}

It is of great importance that all necessary efforts are made to make the sport become a part of the child's natural life from early ages without being missed by the media (29). Turkish society is based on a rich culture and solid family structure, but the sport has positive effects on the physical and psychological development of the individual. In addition, mass sport has not become widespread in our society. Already the number of active sportsmen in our country is very small. Besides, the rate is even lower for those who play sports for health. Particularly female sport attendance is well below normal levels. It is seen that the parents working in the study have children who are 38 males and 23 females, and they are more directed towards the sports than girls.

Ties between family and school help children make the feelings good and thoughts clear. Families with athletic-based sporting cultures prevent children from turning to many unusual behaviors by encouraging their children to pre-school and during school (25). At this point, it is seen that the education about values of judo contributes to the education about values of preschool children. For example, parents have pointed out that their children are guiding the justice to learn about sports culture and morality.

The success of child education in the family is possible by supporting the Turkish Woman and protecting her dignity within the society. "A woman must be healthy and physically healthy so that the children that she is to be raised and the tasks to be undertaken are healthy. To do that, we need to make sure that we are doing sports (gymnastics, running, cycling, etc.) on a regular basis and that our life style is safe, simple and good for all ages ladies to feel good about themselves as well as health, selfconfidence, physical fitness and beauty (15). In all these studies, self-confidence for the individual is very important. Judo has been mentioned in many studies that have contributed to sport's self-reliance. It is known that preschool children will contribute to individual development in the process of being involved as an individual in society.

\section{Conclusion}

The most important factor in the child's sport orientation is the family, which is increased in parallel with the parents' education level, and the children who are encouraged by the sports by their parents have been involved in many academic studies that they have had a healthier socialization process and are more successful throughout their lives. It is also emphasized that adolescents in adulthood are related to sporting activities in childhood.

As a result, it is seen that the education and income levels of parents and the status of being athletes in the family are influenced by sport from early years, especially when many literature studies that affect the attitude towards the sporting of children are positive. It is important to support the knowledge and skills of the child about the sport in the pre-school period as the sport also gives the child a social role by raising discipline, trust, competition and feelings of friendship as well as support for the physical and psychological structure. As an educational activity, sports provide the ability to express common goals, to appreciate, to reinforce understanding, patience, business association and responsibility behaviour and to strengthen individual-community relations $(11,16,19)$. Beginning with baby massage from birth, it is necessary for the child to be introduced to the sport in parallel with the development of knowledge, attitudes and behaviors related to sports and the introduction of sports. These imitations, starting with the mother and father when they have developed the simplest behavioural forms from the first months onwards, can be good role models for all ages in the process of socialization by associating with the sportsmen and the sportsmen (34).

In this study, parents who are role models for children, children of judo sports; it seems that they are guiding their children to judo sports because they want to improve sports culture and morality, social adaptation and self discipline. As a result of comparing these expectations with the contribution of Judo sport to the development of children; it is 
known that in the preschool childhood, judo sports education will provide a strategic plan for the development of psycho-motor development, cognitive and motoric movement development support. It will also be the source of planning for developing children in the preschool period to meet judo sports. It is important to note that the physical and mental development process that is inherent in Judo sports is one of the most important points of support for a child's development. At this point, the experts, trainers and Turkey are important in terms of creating strategic resources which are delivered to be used for the sport of judo in schools of Judo Federation.

\section{REFERENCES}

1. Amman MT. Spor Sosyolojisi. Ed: H.C. İkizler, Sporda Sosyal Bilimler, İstanbul: Alfa Basım, 2000.

2. Ayan V. Mülazımoğlu O. Sporda Yetenek Seçimi ve Spora Yönlendirmede 8-10 Yaş Grubu Kız Çocuklarının Fiziksel Özelliklerinin ve Bazı Performans Profillerinin İncelenmesi (Ankara Örneği). Niğde Üniversitesi Beden Ĕ̆itimi ve Spor Bilimleri Dergisi, 2010, 4 (3): 152-159.

3. Aydoğan Y, Özyürek A. Akduman G. Okul Öncesi Dönem Çocuklarının Spora İlişkin Görüşlerinin İncelenmesi. International Journal Of Science Culture And Sport (Intjscs), 2015, Special Issue 3, Issn: 2148-1148, Doi: $10.14486 /$ Ijscs265

4. Bluechhardt MH. Shephard RI. "Using an Extra curriculum Physical Activitiy Program to Enhance Social Skills", Journal of Learning Disabilities, 1995, 28(3): 160

5. Coakley I. Social Dimensions of Intensive Training and Participation in Youth Sports, Intensive Participation in Children's Sports, 1993.

6. Çamlıyer H. Çocuk Hareket Eğitimi ve Oyun. Can Ofset Yayıncılık, İzmir, 1997.

7. Çelik, A. \& Şahin, M. Spor ve çocuk gelişimi, The Journal of Academic Social Science Studies, JASSS-International Journal of Social Science, 2013, 6(1): 467-478.

8. Çepni S. Araştırma ve Proje Çalışmalarına Giriş. Trabzon: Üçyol Kültür Merkezi Yayınları, 2005.

9. Çevik O. Kabasakal K. Spor Etkinliklerinin, Engelli Bireylerin Toplumsal Uyumuna ve Sporla Sosyalleşmelerine Etkisinin İncelenmesi. Uluslararası Sosyal ve Ekonomik Bilimler Dergisi, ISSN: 1307-1149, 2013, 3 (2): 74-83.

10. Erdal G. Gelișim ve Öğrenme Kuramcılarına Göre Müzik Öğretim Yöntemlerinin Okul Öncesi Eğitimdeki Yeri, International Journal of New Trends in Arts, Sports \& Science Education, 2012, volume 1, issue 4

11. Ergun, N. Bedensel Engelli Çocuk ve Spor. Çoluk Çocuk Dergisi, 2003, 5: 26: 50.

12. Fichter J. Sosyoloji Nedir, (Çev.N. Çelebi). Atilla Kitabevi, Ankara, 1994.

13. Filiz K. Sporun Tanımlanması ve Kapsamının Belirlenmesi Üzerine Bir Çalışma. G.Ü. Gazi Eğitim Fakültesi Dergisi, 2002, 22 (2): 203-211.
14. Heper E. Sporla ilgili kavramlar ve sporun tarihsel gelişimi, Spor Bilimlerine Giriş (Ed.: Ertan H), Anadolu Üniversitesi Yayınları, no: 2509, Eskişehir, 2012.

15. Hergüner G. Çocuğun Spora Yönelmesinde Ailenin Rolü ve Önemi, Ondokuz Mayıs Üniversitesi Eğitim Fakültesi, Beden Eğitimi ve Spor Bölümü Öğr. Gör, 2009.

16. İlhan L. Eğitilebilir Zihinsel Engelli Çocuklarda Beden Eğitimi ve Sporun Sosyalleşme Düzeylerine Etkisi, Kastamonu Eğitim Dergisi, 2008, 3-16 (1): 315-324.

17. Kaplan Y, Çetinkaya G. Spor Yoluyla ToplumsallaşmaYeniden Toplumsallaşma Süreci. International Journal of Science Culture and Sport, 2014, 2: 120-125.

18. Keskin V. Çocuklarını Spora Yönlendiren Anne ve Babaların Beklentileri, Afyon Kocatepe Üniversitesi, Sağlık Bilimleri Enstitüsü, 2006.

19. Korkmaz N.H. Yaz Spor Okulları İle Çocukların Benlik Saygısı Arasındaki İlişki, Eğitim Fakültesi Dergisi XX, 2007, (1): 49-65.

20. Kotan Ç, Yaman Ç. İlköğretim Okullarında Okuyan Sporcu öğrencilerin Spor Yapmalarında Okul Ve Aile Faktörünün Etkisi (Sakarya İl Örneği), Niğde Üniversitesi Beden Eğitimi ve Spor Bilimleri Dergisi, 2009, 3 (1): 49-58.

21. Matsumoto D. Konno J. The Relationship Between Adolescents' Participation in Judo, Quality of Live and Life Satisfaction, 2005, 38-(1):13-25.

22. Milli Eğitim Bakanlığı. Temel Spor Eğitimi Öğretim Programı 9. Sınıf, T.C. Milli Ĕ̆itim Bakanlığı Ortä̈̆̆retim Genel Müdürlüğü, Ankara, 2006.

23. Muratlı S. Çocuk ve Spor, Nobel Akademik Yayıncılık, Ankara, 2013.

24. Nakamura I. EJU Level 4 coaching course of lecture noties. Judo Principles, 2013.

25. Nirun N. Türkiye'nin Sosyal Gelişiminde Ailenin Rolü ve Önemi, I. Aile Şûrası Bildirimleri, 1990, s. 164.

26. Özyürek A, Özkan İ, Begde Z, Yavuz NF. Okul Öncesi Dönemde Beden Eğitimi ve Spor, International Journal of Science Culture and Sport (IntJSCS), ISSN: 2148-1148, Doi : 10.14486/IJSCS314, 2015, Special Issue 3,

27. Stevens J. The Way of Judo A Portrait of Jigoro Kano \& His students, Shambhala Publications, 2013.

28. Şimşek S. İlköğretim 8. Sınıf beden eğitimi dersinin öğrencilerin psikomotor gelişimine katkısı konusunda beden eğitimi öğretmenleri ve öğrencilerinin görüşleri, Yayınlanmamış Yüksek Lisans Tezi, Pamukkale Üniversitesi Sosyal Bilimler Enstitüsü, 1998.

29. Ünsal B, Ramazanoğlu F. Spor Medyasının Toplum Üzerindeki Sosyolojik Etkisi, Eğitim ve Öğretim Araştırmalar Dergisi, ISSN: 2146-9199, 2013, 2(1): 36-46.

30. Watanabe J. Avakian L. The secret of judo (A Text for Instructors and Student). Tuttle Martial Arts Publications, 1960.

31. Wayland J, Pulkkinen BPE. M. Sc, CK. The Sport Science of Elite Judo Athletes (A Review \& application for Training), National Library of Canada Cataloguing in Publication Data, 2001.

32. Yetim A. Sosyoloji ve Spor. Morpa Yayınları, Ankara, 2005.

33. Yücel AS, Kılıç B, Korkmaz, M. Göral K. Spor Yapan Çocukların Spor Tercihleri ve Bunu Etkileyen Bazı Faktörlerin 
İncelenmesi, Uluslararası Hakemli Akademik Spor Sağlık Ve Tıp Bilimleri Dergisi, 2015, 14: 20-54.

34. Yücel M. Gelişim ve Öğrenmenin Spor Kültürünün Oluşmasına Etkisi, Doğu Anadolu Bölgesi Araştırmaları, 2004, 100-108.

35. Ziyagil M, Zorba A, Bozatlı ES. İmamoğlu, O. 6-14 Yaş Grubu Çocuklarda Yaş, Cinsiyet ve Spor Yapma Alışkanlığının Sürat ve Anaerobik Güce Etkisi, BESBD, 1999. 